\title{
PROPHYLACTIC TRANEXAMIC ACID VERSUS AUTOLOGOUS BLOOD TRANSFUSION TO REDUCE BLEEDING IN ELECTIVE CORONARY BYPASS GRAFT SURGERY.
}

\author{
Othman Ismat Abdulmajeed* \\ "MB,ChB, FIBMS, College of Medicine, Hawler Medical University, Erbil, IRAQ.
}

\begin{abstract}
Many blood conservation strategies were developed in the past decades to reduce risk of bleeding and the need for blood products among patients undergoing cardiac surgeries. This study was conducted to define the benefit of reinfusion of preoperative collected autologous blood in reduction of the risk of bleeding and the need for blood and blood products in comparison with tranexamic acid.

This single centre single-blinded, randomized study was conducted in Erbil cardiac centre during the period from $1^{\text {st }}$ of November 2018 to $30^{\text {th }}$ of April 2019. A total of 150 patients were divided into three groups with 50 patients for each. The 1 st group received nothing, the 2nd group received initially infusion of $200 \mathrm{mg} / \mathrm{hr}$ of tranexamic acid until reaching $1.5 \mathrm{gm} / \mathrm{hr}$, and the 3rd group received one pint of preoperative auto-transfused whole blood. Data on risk of bleeding and the need for blood and blood products were collected using special questionnaire prepared for the reason of this study and were analyzed using appropriate statistical tests.

Patients receiving autologous blood showed lower chest tube drainage than the other study groups with a $p$ value of $<0.001$. Similarly the need for blood and blood products intra or postoperatively was significantly lower among patients receiving autologous blood with $p$ value of $<0.001$. Therefore, the risk of intra and postoperative bleeding was significantly lower among those receiving autologous blood when compared to other study groups.

In conclusion, reinfusion of one pint of preoperative collected autologous blood is higher than tranexamic acid in reducing the risk of postoperative bleeding and the need for blood and blood products among patients undergoing cardiac surgery.

Keywords: Autologous, tranexamic acid, bleeding, cardiac surgery, Coronary bypass.
\end{abstract}

\section{Introduction}

$\mathrm{O}$ ne of the major complications that threaten the life of patients during and after cardiac surgery is bleeding ${ }^{1-3}$. Reducing the risk of bleeding and the need for blood products remains the main concern among cardiac surgeons during preoperative period ${ }^{4}$. To achieve this goal, many blood conservation strategies were developed in the past decades ${ }^{4,5}$. Among these different strategies, antifibrinolytic drugs were used in open cardiac operations ${ }^{5}$, of these drugs, tranexamic acid was the more potent antifibrinolytic drug that achieve sufficient reduction in the risk of bleeding and the need for blood products 5 . However, due to safety concerns, tranexamic acid use in cardiac surgery remains underutilized and controversial $^{6,7}$. On the other hand, autologous blood transfusion as another strategy provides reduction in the need for blood products and improves the coagulation process during cardiac surgery, This procedure is simply including preoperative collection of patient own blood and reusing it during or after cardiac operation ${ }^{8}$. The main 
advantages of this procedure are elimination of infection risk (viral hepatitis, cytomegalovirus, HIV) and alloimmunization, lack of $\mathrm{Rh}$ incompatibility, preserving immune system, keeping the integrity of RBCs, platelets and clotting factors, and preventing transfusion related lung injuries associated with homologous blood transfusion ${ }^{9,10}$. On the other hand, some disadvantages of this procedure were also reported including wastage of collected autologous blood if not used during operation, subjecting the patient to preoperative anaemia, risk of $\mathrm{ABO}$ incompatibility are not eliminated, and risk of bacterial contamination during post blood collection period is not reduced $^{8}$. In the recent years, gradual attention on the use of autologous blood transfusion on patients undergoing cardiac surgery has been attracted clinicians due to increasing problem of blood safety and blood bank shortage ${ }^{11}$.

This study was conducted to define the benefit of reinfusion of preoperative donated semi-autologous blood in reduction of the risk of bleeding and the need for blood and blood products in comparison with tranexamic acid.

\section{Patients and Methods}

This single centre, single-blinded, randomized prospective comparative study was conducted in Erbil cardiac centre during the period from $1^{\text {st }}$ of November 2018 to $30^{\text {th }}$ of April 2019.

A total of 150 patients younger than 80 years of age undergoing first time elective coronary artery bypass graft $(\mathrm{CABG})$ at Erbil cardiac centre were enrolled in this study.

Patients with weight more than $100 \mathrm{~kg}$, having uncontrolled hyper or hypotension, congestive cardiac failure, atrioventricular or left bundle branch block, or a pacemaker in-situ, patients with valvular heart disease, previous CABG surgery, misuse of alcohol or drugs, severe hepatic or renal insufficiency were excluded from this study.

The included patients were divided into three groups with 50 patients for each. Patients in the 1 st group received nothing, patients in the 2nd group received initially an infusion of $200 \mathrm{mg} / \mathrm{hr}$ of tranexamic acid until reaching $1.5 \mathrm{gm} / \mathrm{hr}$, and patients in the 3rd group received one pint of preoperative collected autotransfused whole blood. This blood was collected from the same patient just before starting surgery.

Patients data were selected using special questionnaire prepared for the reason of this study. Variables including demographic (name, age, gender), history of chronic diseases (hypertension, diabetes mellitus, chronic obstructive pulmonary diseases), lipid profile, chest tube drain at operation room and intensive care unit during 1 st and 2nd 24 hrs post operatively.

Data were analyzed by using the Statistical Package for Social Sciences (SPSS) version 23. Descriptive statistics are presented as mean \pm standard deviation, frequencies and percentages. Multiple contingency tables were conducted and appropriate statistical tests were performed, Chi-square was used for categorical variables, analysis of variance (ANOVA) was used to compare between means of the different study groups.

\section{Results}

Significant differences ( $\mathrm{P}$ Value $=0.009$, $<0.05$ ) was found among the three study groups in term of hypertension which was significantly lower among group B \& C than group A. No significant differences in remaining patients characteristics were reported, as shown in Table I. 
Table I: Patients characteristics among the three study groups.

\begin{tabular}{|c|c|c|c|c|c|}
\hline & & $\begin{array}{l}\text { Placebo } \\
\text { Group }\end{array}$ & $\begin{array}{l}\text { Tranexamic } \\
\text { Group }\end{array}$ & $\begin{array}{l}\text { Autologous } \\
\text { Group }\end{array}$ & $\mathrm{P}$ value \\
\hline \multicolumn{2}{|l|}{ Age $($ Mean \pm SD) } & $65.54 \pm 7.87$ & $63.30 \pm 8.58$ & $66.30 \pm 7.88$ & $0.152 *$ \\
\hline \multirow{2}{*}{ Gender } & Male & $25(50 \%)$ & $20(40 \%)$ & $21(42 \%)$ & \multirow{2}{*}{$0.566 * *$} \\
\hline & Female & $25(50 \%)$ & $30(60 \%)$ & $29(58 \%)$ & \\
\hline \multirow{2}{*}{ HPT } & yes & $48(96.0 \%)$ & $37(74 \%)$ & $40(80 \%)$ & \multirow{2}{*}{$0.009 * *$} \\
\hline & No & $2(4.0 \%)$ & $13(26 \%)$ & $10(20 \%)$ & \\
\hline \multirow{2}{*}{$\mathrm{DM}$} & yes & $30(60 \%)$ & $36(72 \%)$ & $31(62 \%)$ & \multirow{2}{*}{$0.404 * *$} \\
\hline & No & $20(40 \%)$ & $14(28 \%)$ & $19(38 \%)$ & \\
\hline \multirow{2}{*}{ Hyperlipidemia } & yes & $29(58 \%)$ & $35(70 \%)$ & $32(64 \%)$ & \multirow{2}{*}{$0.457 * *$} \\
\hline & No & $21(42 \%)$ & $15(30 \%)$ & $18(36 \%)$ & \\
\hline \multirow{2}{*}{ COPD } & yes & $12(24 \%)$ & $20(40 \%)$ & $13(26 \%)$ & \multirow{2}{*}{$0.163 * *$} \\
\hline & No & $38(76 \%)$ & $30(60 \%)$ & $37(74 \%)$ & \\
\hline
\end{tabular}

*ANOVA, ${ }^{* *}$ ChiSquare

Postoperative chest tube drain during the 1 st and 2nd 24hours was significantly lower among group receiving autologous blood than those groups receiving nothing or receiving tranexamic acid with $\mathrm{P}$ value of $<0.0001$ as shown in Table II.

Table II: Chest tube drainage during 1st and 2nd 24 hours postoperatively

\begin{tabular}{|l|l|l|l|l|}
\cline { 2 - 5 } \multicolumn{1}{c|}{} & $\begin{array}{l}\text { Placebo } \\
\text { Group }\end{array}$ & $\begin{array}{l}\text { Tranexamic } \\
\text { Group }\end{array}$ & $\begin{array}{l}\text { Autologous } \\
\text { Group }\end{array}$ & P value \\
\hline Drainage during 1st 24 Hr & $719 \pm 123.09$ & $732 \pm 80.5$ & $279.7 \pm 43.3$ & $<0.0001^{*}$ \\
\hline Drainage during 2nd 24 Hr & $62.5 \pm 19.92$ & $62.9 \pm 19.4$ & $23.2 \pm 8.3$ & $<0.0001^{*}$ \\
\hline
\end{tabular}

*ANOVA

Significant differences among the three study groups in terms of packed red blood cells (PRBC), plasma, and platelets needs, being lower in group receiving autologous blood than those groups receiving nothing or receiving tranexamic acid with $P$ value of $<0.0001$ for each, as shown in Table III.

Table III: Intra and post-operative data

\begin{tabular}{|c|c|c|c|c|}
\hline & $\begin{array}{l}\text { Placebo } \\
\text { Group }\end{array}$ & $\begin{array}{l}\text { Tranexamic } \\
\text { Group }\end{array}$ & $\begin{array}{l}\text { Autologous } \\
\text { Group }\end{array}$ & P value* \\
\hline PRBC - OT & $78(34.2 \%)$ & $80(38.6 \%)$ & $0(0.0 \%)$ & \multirow{3}{*}{$<0.0001$} \\
\hline PRBC-ICU & $150(65.8 \%)$ & $127(61.4 \%)$ & $82(100.0 \%)$ & \\
\hline PRBC - Total & 228 & 207 & 82 & \\
\hline Plasma - OT & $150(60.0 \%)$ & $150(60.0 \%)$ & $0(0.0 \%)$ & \multirow{3}{*}{$<0.0001$} \\
\hline Plasma - ICU & $100(40.0 \%)$ & $100(40.0 \%)$ & $50(100.0 \%)$ & \\
\hline Plasma -Total & 250 & 250 & 50 & \\
\hline Platelets - OT & $150(60.0 \%)$ & $150(60.0 \%)$ & $0(0.0 \%)$ & \multirow{3}{*}{$<0.0001$} \\
\hline Platelets - ICU & $100(40.0 \%)$ & $100(40.0 \%)$ & $50(100.0 \%)$ & \\
\hline Platelets - Total & 250 & 250 & 50 & \\
\hline
\end{tabular}

*Chi Square. 
Post-operative bleeding is significantly lower in group receiving autologous blood than those groups receiving nothing or receiving tranexamic acid with a $\mathrm{P}$ value of 0.018 , as shown in Table IV.

Table IV: Post-operative bleeding data among the three study groups.

\begin{tabular}{|c|c|c|c|c|c|}
\hline & & $\begin{array}{l}\text { Placebo } \\
\text { Group }\end{array}$ & $\begin{array}{l}\text { Tranexamic } \\
\text { Group }\end{array}$ & $\begin{array}{l}\text { Autologous } \\
\text { Group }\end{array}$ & P value* \\
\hline \multirow{2}{*}{$\begin{array}{l}\text { Post-operative } \\
\text { bleeding }\end{array}$} & yes & $11(22.0 \%)$ & $\begin{array}{ll}5 & (10.0 \%) \\
\end{array}$ & $2 \quad(4.0 \%)$ & \multirow{2}{*}{0.0187} \\
\hline & No & $39(78.0 \%)$ & $45(90.0 \%)$ & $48(96.0 \%)$ & \\
\hline
\end{tabular}

*Chi square test

\section{Discussion}

Patients undergoing cardiac surgery suffers from severe damage to blood components (RBCs, WBCs, platelets, and clotting factors) thus exposing these patients to increased risk of bleeding post-operatively and increased the needs to blood and blood products ${ }^{8,10}$, this encourage the cardiac surgeons to search for procedures that help in reduction of risk of bleeding and the need for blood and blood products ${ }^{10}$.

$\mathrm{Oz}$ et $\mathrm{al}^{10}$ reported no significant differences among patients undergoing cardiac surgery and using autologous blood compared to patients using homologous blood in terms of hypertension with $\mathrm{p}$ value of 0.06 . However, in the current study, there were significant differences between the study groups in terms of hypertension with $p$ value of 0.009 . On other hand, $\mathrm{Oz}$ et al reported significant differences among patients undergoing cardiac surgery and using autologous blood compared to patients using homologous blood in terms of diabetes mellitus and hyperlipidaemia with $p$ value of 0.002 and 0.03 respectively. While, Huseyin et $\mathrm{al}^{9}$ reported non-significant differences among patients undergoing cardiac surgery and using autologous blood compared to patients using homologous blood alone or combination of autologous and homologous in terms of diabetes mellitus with $\mathrm{p}$ value more than 0.05 . However in the current study, nonsignificant differences were reported between the study groups in terms of diabetes mellitus and hyperlipidaemia with $p$ value of 0.40 and 0.45 respectively.

$\mathrm{Oz}$ et $\mathrm{al}^{10}$ reported that chest tube drainage was significantly $(<0.0001)$ lower among patients receiving autologous blood than those receiving homologous blood with $p$ value of $<0.0001$. Similarly, blood transfusion intra-operatively and post-operatively was significantly lower among those patients receiving autologous blood than those receiving homologous blood with $\mathrm{p}$ value of 0.025 and 0.018 respectively ${ }^{10}$. On the other hand, Huseyin et $\mathrm{al}^{9}$ reported that blood transfusion was significantly lower among those patients using autologous blood compared to patients using homologous blood alone or combination of autologous and homologous with $p$ value of $<0.05$. In the current study, chest tube drainage during 1 st and 2nd $24 \mathrm{hr}$ was significantly lower among patients receiving autologous blood than those receiving nothing or receiving tranexamic acid with $p$ value of $<0.0001$. similarly, PRBCs needs was significantly lower among patients receiving autologous blood than those receiving nothing or receiving tranexamic acid with $p$ value of $<0.0001$.

Huseyin et $\mathrm{al}^{9}$ reported no significant differences in plasma need between patients receiving autologous blood compared to those receiving homologous blood alone or combination of autologous 
and homologous with $\mathrm{p}$ value of $>0.05$, while in the current study, plasma need intraoperatively and postoperatively was significantly lower among patients receiving autologous blood than those receiving nothing or receiving tranexamic acid with $p$ value of $<0.0001$.

Luque-Oliveros et $\mathrm{al}^{11}$ reported that reinfusion of $\leq$ one pint $(\leq 580 \mathrm{ml})$ of autologous blood is statistically significant $(<0.01)$ in reducing the risk of postoperative bleeding in patients undergoing cardiac surgery. Huseyin et $\mathrm{al}^{9}$ reported that risk of bleeding is significantly lower among those patients using autologous blood compared to patients using homologous blood alone or combination of autologous and homologous with $p$ value of $<0.05$. Oz et al ${ }^{10}$ reported significant differences in risk of postoperative bleeding in those receiving autologous blood compared to those receiving homologous blood with $\mathrm{p}$ value of $<0.01$. in the current study, risk of postoperative bleeding was significantly lower ( $p$ value $=0.018$ ) in those patients receiving autologous blood when compared to those receiving nothing or those receiving tranexamic acid.

In conclusion, reinfusion of one pint of preoperative collected autologous blood is higher than tranexamic acid in reducing the risk of postoperative bleeding and the need for blood and blood products among patients undergoing cardiac surgery.

\section{References}

1.Robich MP, Koch CG, Johnston DR, et al. Trends in blood utilization in United States cardiac surgical patients. Transfu-sion 2015; 55: 805-14.

2.Biancari F, Mikkola R, Heikkinen J, Lahtinen J, Airaksinen KE, Juvonen T. Es-timating the risk of complications related to re-exploration for bleeding after adult cardiac surgery: a systematic review and meta-analysis. Eur J Cardiothorac Surg 2012; 41: 50-5.

3.Myles PS, Smith JA, Forbes A, Silbert B, Jayarajah M, Painter T, et al. Tranexamic Acid in Patients Undergoing Coronary-Artery Surgery. N Engl J Med 2017;376:136-48.

4.Poeran J, Rasul R, Suzuki S, et al. Tranexamic acid use and postoperative outcomes in patients undergoing total hip or knee arthroplasty in the United States: retrospective analysis of effectiveness and safety. BMJ. 2014;349:g4829 - 38 .

5.Ali Shah MU, Asghar MI, Siddiqi R, Chaudhri MS, Janjua2 AM, Iqbal A. Topical application of tranexamic acid reduces postoperative bleeding in open-heart surgery: Myth or fact? Journal of the college of physicians and surgeons Pakistan 2015; 25(3): 161-5.

6.Yates j, Perelman I, Khair S. Taylor J, Tinmouth A, Saidenberg E. Exclusion criteria and adverse events in perioperative trials of tranexamic acid: a systematic review and metaanalysis. Transfusion. 2019;59(2):806-824.

7.Baric D, Biocina B, Unic D, Sutlic Z, Rudez I, Vrca VB, et al.Topical use of antifibrinolytic agents reduces postoperative bleeding: a double-blind, prospective, randomized study. Eur J Cardiothorac Surg 2007; 31:366-71.

8.Hussain BS, Reddy SV, Prasad LN , Madhavi G. Autologous blood transfusion in open heart surgeries under cardiopulmonary bypass -Clinical appraisal. JMed Allied Sci 2017;7(1):48-54.

9.Huseyin S, Yuksel V, Guclu O, Turan FN, Canbaz S, Ege T, Sunar H. Comparison of early period results of blood use in open heart surgery. J Res Med Sci. 2016 May 9;21:28.

10.Oz BS, Arslan G, Kaya E, Gunay C, Cingoz F, Arslan M. Comparison of results of autologous versus homologous blood transfusion in open-heart surgery. Cardiovasc J Afr. 2013;24(4):121-129.

11.Luque-Oliveros M, Garcia-Carpintero MA, Cauli O. Blood Infusion and the Risk of Haemorrhage in Patients Undergoing Cardiac Surgery with Extracorporeal Circulation. Current Vascular Pharmacology 2017; 15(6): 576-81. 